\title{
The Inside and Outside: Religious Experience and Religious Thought
}

\author{
ROBERT S. GALL \\ Untversity of Wisconsin - Whitewater
}

My purpose in this essay is to explore religious experience and religious thought and the relation between the two, for how these two are conceived has an important bearing on how we understand the meaningfulness of religion and religious traditions. My starting point is Peter Berger's recent work, The Heretical Imperative (Anchor/Doubleday, 1980), in which he summarizes the various strategies for pursuing theology and religious thinking in our contemporary situation. There Berger notes the following:

This book is an argument, an exercise in religious thought, not a confessional document or a guide to religious experience. It is all the more important to keep in mind that religion is not primarily a matter of reflection or theorizing. At the heart of the religious phenomenon is prereflective, pretheoretical experience (334; my emphasis).

Here Berger sketches a view of religion, religious experience and religious thought that is not at all unfamiliar. Religious experience--what is called faith or "personal religion" by others and is characterized as the inner sense of overwhelming reality that comes from an encounter with what is sacred--is considered to be the heart and soul (the essence) of that phenomenon called religion. The assumption is that, since one need not be learned in the intricacies of theology. philosophy or ecclesiology in order to have it, faith clearly must be the common denominator among adherents to any particular religion (including the "founder" of the religion). Thus religious experience must be the core, the pure and simple origin that serves as the ground of all religious affirmations and thereby gives rise to tradition and reflection. Prior to all theories about it (123), religious experience posits its own authority beyond the relativities of history and mundane experience (50), beyond all rationality (135), such that 
the conviction that one has encountered God and heard his voice is not touched by the relativizations of historical consciousness. There are these encounters that carry within them an intrinsic conviction of truth. The individual can find certainty in this conviction. Even if he enters into the full gamut of historical and social scientific relativizations he can be confident that what has been experienced as truth by himself. . will never come to be seen as untruth (139; my emphasis).

Here Berger re-enforces what we have said: religious experience is the secure and unassailable essence and presence of religion beyond the variations of time and tradition. Tradition and reflection are necessarily secondary phenomena, on the outside, "expressions" that are envigorated and given life (meaning) by religious experience. Even when it might be admitted that religious experience and its outward expressions form a sort of "dialectic," this is only to say that religious thought and language "color" religious experience itself.' Indeed, since they are "inevitably distortive" (49) in their reflection and representation of religious experience, tradition and reflection might be more properly called parasites which "feed off" their host, proximate to yet distant from religious experience, nearby yet wholly other. If we are to know the religion as it is, we must come to know religious experience: that is the key to understanding religion.

As we have said, this view is not unfamiliar. For instance, in Christian theology over the last two centuries we have seen the "feeling of absolute dependence" as the essence of positive religion (Schleiermacher). "subjective truth" (Kierkegaard), the gift of Word and faith as a given that precedes all tradition and reflection (i.e. empirical Christianity) (Barth). and "ultimate concern" with "Being itself" that may only be inadequately represented by symbols ( $T i l i \mathrm{ch}$ ). Today, it is a commonplace for texts in philosophy of religion to define their subject as a philosophical thinking about religion, i.e., a consideration of religious concepts and propositions from outside the religious realm. Philosophy of religion is then at best a second-order activity "at one remove from its subject matter." Likewise, the popular "historian" of religion Wilfred Cantwell Smith makes the distinction between faith (one's inner experience or involvement with the transcendent) and the accumulated historical expressions and beliefs of a tradition (that "decorate or bespatter our world diversely") the cornerstone of his argument for the essential unity of and continuity between different faiths, and his project of a world theology. "Theologians such as Langdon Gilkey" and David Tracys regularly appeal to an experiential or ex- 
istential level of religious life and community as the criterion for theological proposals, a level that presumably cannot be determined in advance by metaphysical construction or transcendental analysis. All these examples have at their foundation the same assumption that informs Berger's thought: religious experience or "faith" is the inter core, the fundamental datum of religion; tradition and reflection are outward expressions or secondary realities. As we can see, this approach to religion 18 the basis for nearly every meditation done today that attempts to take religion seriously, i.e., that acknowledges the unique claim of religion and therefore resists reducing it in toto to some other reality (e.g., society, psychology, history). In order to parry philosophers, social scientists and others who criticize religion in light of its "rational," "cognitive," outward expressions, those who are sympathetic to religion (as in the case of these theologians and philosophers of religion) find themselves bound to remove religious experience and the encounter with the sacred from the contingencies of culture, language and the like. In this way one secures for religion a place among the valid and truthful activities of human beings.

Yet Berger's discourse (like that of others), despite the references that we have cited to a pure and simple religious experience, spends little time on religious experience "as such." lis concern, rather, is with the modern situation, our current historical and cultural setting in which there is an apparent lack of religious experience. His project is to help us with the "heretical imperative" put to us by our' aituation, i.e., the necessity today of choosing some religious affirmation that makes sense from amidst a variety of possibilities presented to us. Chastising neoOrthodoxy (in the figure of Karl Barth) for attempting to ignore the modern situation with an affirmation of faith that is presumably not subject to history and human experience (61ff), Berger, following Schleiermacher, urges on us an inductive method for affirming religion (114ff), one that explores the history and setting of religion--its symbolic expressions of experience--with all the tools of the historian and the social scientist. This is because religious experience, not being uniformly distributed and unable to be sustained over time (43), necessarily and inevitably comes to be "embodied" in tradition and reflectio:.. The latter, imbued with the authority of religious e:perience (44). serve as the "frozen memories," the signs and traces, which we must investigate in pursuit of religious experience, and by whose uncertain measure we must weigh the truth or falsity of the experience (135).

This however means that religious experience is never present to us as such. Our very pursuit of it by 
the inductive method invokes its absence, an absence that is forever with us since, according to Berger, one never fully attains one's goal (50). Infinitely deferred by being differed from itself in signs and traces (tradition and reflection), religious experience is emptied of its substance; the host has become ghost and guest, a haunting stranger amidat the relativities of time and culture through which we wander. What this means, however, is that, instead of being bracketed out of play (or paradoxically, by being bracketed out of play), religious experience is subject to and constituted by the interplay of language, thought and reality that is the movement of time, history and tradition. This play of the world, this movement, is "what" Jacques Derrida has called differance, the spacing and timing (differing and deferring) that "produces" the play of differences between things." Differance names the co-origination of sign and signified, the implication of the sign in the signified. Berger has thought, true to his freely acknowledged phenomenological presuppositions, that religion, to be meaningful and significant, must have that meaning and significance 10cated in itself, present to itself, in some pure and simple "transcendental signified" to which we point with signs and symbols. Yet unassailable and secure in itself, religious experience is in-significant to us by Berger's own account, for it is not sustained and does not last. It only becomes significant when it becomes its other, 1.e. when it transfers its authority and becomes "embodied" in tradition and reflection. In other words, religious experience is only significant when it becomes sign, which is why it does not last and must become embodied in tradition and reflection. "Erom the moment that there is meaning there are nothing but signs." I

Put another way, the thing in itself (in this case, religious experience) is a sign; religious experience must already be a sign, a trace, a text (all "metaphors" of exteriority in Derrida's analyses), in order to be meaningful and significant. For instance, it is Berger's argumentation, his religious thought, that delineates, de-scribes and de-signates the importance of religious experience; religious experience is significant as the pre-text for taking the historical "expressions" of religion seriously. Religious experience, then, is not pure and simple; it is already written and traced, a "text" demarcated by tradition and reflection (religious thought) and thereby bound to them. Religlous experience and religious thought--the "inside" and the "outside"--are indeed woven together, joined together, co-texts that form a con-text from which meaning emerges. (Berger admits as much when he notes that "the reifigious experience and the symbolic apparatus mutually determine one another" (47)). All of which is to say, following a practice of Martin Heideg- 
ger and Jacques Derrida, that the inside $Z 6$ the outside; religious experience religious thought.

This destructive-deconstructive strategy of inscription and erasure ( $($ ) is a necessity in a situation such as this in which our (metaphysical) language is no longer adequate to describing the "relation" between religious experience and religious thought. Each is a text, an interpretation, of whatever $1 \mathrm{~s}$ considered to be the matter at stake. The two then are the same; hence the "is." Yet these two do not form an indifferent identity that reduces one to the other; each is outside the other and likewise encloses and is enclosed by the other, whereby it is impossible for us to tell which commands. To pass from one to the other is not a case of simple translation, a simple substitution of terms (as Berger himself indicated when, giving precedence to religious experience, he called tradition and reflection "distortive"). A certain "violence" is in play between the two, with both inhabiting the other yet exceeding the other, each playing the role of parasite and host in a strange sort of communion that binds them together. 10 Thus we are driven to "cross out" the "is" to avoid the metaphysical implications of substantial identity that do not apply to these two "texts" that are more "activity" and "process" than thing. Religious experience and religious thought are the same, yet different; to pass from one to the other engenders a transformation, a movement of spacing and alterity that is the play of differences from which meaning emerges.

Some might suppose that this analysis confirms a dialectical relationship between religious experience and religious thought. Even those indebted (and presumably dedicated) to the thinking of Heidegger and Derrida (e.g.. Thomas J. J. Altizer, Mark Taylor, Paul Ricoeur, Hans-Georg Gadamer) ${ }^{12}$ often draw heavily on a Hegelian-influenced dialectic in developing this line of thought, and in applying it to the matter of religion and religious thinking. Yet this "relationship" between religious experience and religious thinking is not a matter of unavoidable mediation and dialectic. and we would be remiss in so interpreting the destructive-deconstructive analysis above. In a dialectic (whether implicitly or explicitly) the negative, the other, is a resource for the full appropriation of meaning and realization of self-consciousness (selfpresence): the tension and violence between the "inside" and the "outside" is reconciled in an encompassing unity that recaptures and reappropriates (i.e., takes back in) what has been expressed for an absolute self-consciousness. We have seen, however, that we do not have "positive" or "negative" terms here (as if either religious experience or thought were more basic than the other) and that religious experience itself has been emptied, become a sign, in the movement and 
play of differences. Instead of an Aufliebung that neatly closes the horizon of meaning, there is a goingforth, an emergence, an "expenditure without reserve" in this "movement."12 In this "movement" and "play" something is ventured, at risk; there is no certainty or assurance here. The seeds of meaning and truth are disseminated, scattered to the winds (so to speak), to bear fruit (or die) on the way.

This analysis suggests a number of important conseguences for our understanding of religious experience. First, the traditional notion of religious experience (or some correlate) as an ultimate and authoritative "court of appeal" for justification of particular religious assertions is an empty notion; it is a "wheel that does no work," as Wittgenstein might say. This is because (and this is our second point) religious "experience," in some way yet to be decided, always has been thoughtful and "thinking," emerging as it does from the tradition and reflection of its time. For instance, the Buddha's "experience" of enlightenment under the Bodhi tree was a thoughtful meditation that considered the thinking and tradition of his time and laid out and argued for a different interpretation [Auslegung] of the way things are. Likewise, Jesus' "falth" and "experience" of God was a consideration of the "logical" (though radical) implications of the meaning of God as his tradition understood Him (righteous, good, helping, saving), and his life and deatl was an attempt to demonstrate (i.e., to show, prove, explain) this understanding of God. Even the mystic (East or West), the epitome of the emphasis in religion on experience, is involved in thinking about the "True Self" or one's right relation to God, and finds himself compelled to lay out (i.e., interpret--German auslegen) in word and deed whatever knowledge he obtains. In all these cases, and in any others we may wish to cite, "experience" has been taking cognizance of one's situation, thinking about the questions and answers given to one by the tradition and which have helped shape one's "experience," and then risking an answer that tries to make sense of, and tries to show, the way things are. Religious experience therefore has not, is not and cannot be a safe haven from the relativities of history and culture, but must be a venture out into the world, a journey (cf. Er-fahrung in German) that lets meaning shine forth in $i$ ts demonstration of how things are, a demonstration that opens up the four corners of th: world (Heidegger's Geviert, the "fourfold" of earth, sky, divinities and mortals, that is hinted at with the "crossing out" of the "is" (Bethal)" whereby what is divine is encountered. Of course, if this is so, then the experience is open to elaboration, interpretation. rebuttal and contradiction. Indeed, this--our third point--is perhaps the most important point we are making: religious "experience" not only emerges from 
the tradition and reflection of its time, such that it is already a "thinking." but religious "experience" is also constituted and made real by the interpretation and "thinking" that comes later. In other words, religious "experience," as a venture out into the world, is significant in the process of thinking about that "experience," and makes sense only in being interpreted. This of course is the risk and adventure, that religious "experience" is both guestionworthy and questionable, and thereby subject to the intertextuality of the play of the world. We cannot say that "modes of experience in themselves cannot contradict each other"1" and thereby avoid the clash of ideas among the religions of the world. We cannot say, as Berger does, that one's experience of truth "will never come to be seen as untruth" (139). The "hermeneutics of suspicion" of Marx, Nietzsche and Freud that makes up an essential part of the thinking of Heidegger and Derrida should have taught us by now that "experience" and "consciousness" are not unquestionable in this way; indeed, their very questionableness is what makes them significant (questionworthy). In addition, all instances of conversion, and the founding of many religious traditions, would be incomprehensible if religious experience were not "thought" and thereby open to debate.

The emptiness of the traditional notion of religious experience enphasizes all the more the need to reconsider religious thinking. In fact, religious thinking needs to be addressed and stressed more fully, to emphasize the need for inverting and reversing the old opposition between religious experience and religious thought as a prelude to, or indication of, the elimination of such an opposition. ${ }^{13}$ H. re again we may look to the erasure of the "is," for it does more than indicate the destruction of the notion of substance and presence in the relation betwen religious experience and religious thinking. It also indicates that we are at the farthest reaches of our metaphysical language, on the edge of a language where it begins to break up. Hence in crossing out the "is" a border, a line, is marked, marking the way that is the fitting place of our thought. Here religious thinking is bound to work from within and without. Within, thinking works most faithfully and intimately and thereby corresponds [entsprechen] to what has gone before by representing it. Yet such representation is not as traditionally thought, i.e., as the duplication, expression and objectification (however inadequate) of some fixed, fundamental standpoint or experience. Instead, there is a re-presentation in the sense of bringing-forth, of letting meaning once again emerge and show itself by responding to and "speaking against" [ent-sprechen] what has been out of difference. Hence "thinking" works outside as well, an outside that it does not know nor 
name because it is in the process of emerging and being created. Meaning emerges from the differing (from the past) and deferring (of the future), making thinking as much an "origin" (though this too is thought "sous rature"-under erasure--as indicated by the scare quotes) as the traditional notion of experience. But in fact where thinking is now an enactment of what it is about, " beginning and end, origin and future have Ifte sense and indeed vanish in this marginal twilight zone. Indeed, both abiding in and creating this event of meaning [Ereignis] amidst the play of differences, on the cutting edge "between" what is thought and unthought, "between" past and future, we are in a place that is neither inside nor outside, neither peaceful homeland nor alien land of hostility, and are therefore denied the certainty of the rules that govern either side. Yet we are most faithful to ourselves and who we are by inhabiting this risky and ambiguous transgression that is always at work. Instead of willfully attempting to reappropriate the past and thereby maintain the status quo, we are only authentically ourselves in giving up our (old) selves."'

The implications of this analysis for our understanding of religion and religious traditions are varied and far-reaching. For one thing, our understanding of the dynamics of religious traditions is greatly altered. No longer a self-conscious, methodical attempt to match some original experience or discourse to changing circumstances through apology and justification, religious traditions may now be seen as creative processes through which an understanding of the world (i.e., what is and is not possible) is brought-forth, ventured and revealed in and out of differing from other understandings "within" the tradition, and in and out of differing from other traditions as well. Tradition becomes a series of rifts, tears and transgressions from which meaning emerges, a compilation of glosses that does not gloss over into an ever-present Meaning. This is an especially radical understanding for Western traditions, for it signals the end of the Book (as either arche or telos)--i.e.. the end of a fully inscribed meaning, an ordered totality (authored by God)"--and a resiltant shifting and wandering of the locus of meaning from text to text. In fact, the paradigmatic tradition for this sort of understanding would undoubtedly be the Buddhist tradition, particularly the Mahāyaña. With the disclosure of the emptiness of all truths (dharmas) by Nãgärjuna and the Madhyamika school, that tradition found itself free from any attachment to a canon (i.e.. the Pali canon) and allowed for the creation and proliferation of "scriptures" (and lack of scripture, as in the case of zen) that serve as the inspiration for the varying and differing schools of Buddhism and gives the Mahăyāna tradition its peculiar dynamism. (Something of the 
same sort, of course, has gone on in other traditions-e.g. the proliferation of "authoritative" texts and commentaries in Judaism or Hinduism--though always under the guise of being anchored in the true revelation of a book or person). Like Nāgārjuna, our analysig notes that present religious thought is infected with an attachment--to some posited experience, discourse, or tradition--that is stifiing and ultimately nihilistic, for it is an attachment to what is not there and never will be there (i.e.., an attachment to nothing), but what we want to be there. The "rage for order," then, is not "bilessed" but diseased. Religious thought must become aware of the fact that the whole concept of tradition is tenuous at best, that it is less a thing to be grasped, defined and maintained (a whole, a totality) than a meaning that is realized as it is defined. This, plus the understanding that theological work is as much gospel as the Gospels, puts an added burden and responsibility on the theologian and religious thinker, who, unsure of his tradition and place, must have the courage to lead, creating and proclaiming his message (if he has one) rather than giving us old wine in new skins.

The extent to which that burden is being avoided today may be seen not only in the philosophers and theologians we have already mentioned, but also, as already hinted, in the current discussion of the plurality of religions. The responses to this problem of conflicting truth claims have generally sought convergence of one sort or another, whether it be in a common referent (God, Ultimate Reality), transcendental categories or a common, underlying experience (faith). Levelling down the differences by which "experiences" and religious discourse are meaningful, such procedures render religion and religious traditions insignificant. Religious thinkers should instead be taking up the task of thinking in and out of the differences and conflicts of different traditions and "experiences," such that the plurality of religions becomes a bounty of possibilities that challenge our thinking and the way we are. 1 .

Another implication of understanding religious thinking as activity is that all religious practices and activities (including the "experience" of the sacred) may be construed as a kind of thinking. This is not meant to "intellectualize" religious practice, since we have not sketched "thinking" in terms of logic, ratio or other method of the mind. On the contrary, we find ourselves in agreement with the general emphasis today that all the activities associated with religion, including the practice of theology, are on a par as attempts to bring-forth and show an understanding of the world. However, since this precludes any straightforward division between theory and practice (since the theory is activity and the practice is 
"thinking"), the defense and affirmation of a particular tradition or religion in general by appeal to the so-called "existential" level of religion (as in "You cannot really know what IIslam, Christianity, religion, etc.l means unless you are la Muslim, a Christian, religious, etc.]." i.e." unless you practice religion) is no longer valid. A tradition does not escape criticism by appealing to some existential level, because thinking is existential, and touches the heart of the understanding of a particular tradition. The only "defense" of the tradition is a good offense (to the tradition): a demonstration that shows the meaning-fullness of a tradition must be true to the openedness of human existence and the play of the world, rather than to a past which we "want to say" [Vouloir-dire--mean], which we want to be meaningful.

Though this analysis has radically called into question the boundaries of such concepts as "religious experience" and "religious thought," our point has not been to simply do away with such terms: we may still wish to use such terms in certain situations. Instead, in the end, the whole point of this analysis has been to stress the risks and responsibilities of religious (and even "non-religious") thinkers in their particular practices and beliefs--risks and responsibilities that are all too often shunned these days. Positing some unquestionable origin or experience as the foundation of religious thought and tradition overlooks the fact that it is the thinker who is projecting and positing such an origin (i.e.. that it originates with him as much as with anything else) and thereby avoids responsibility for one's own actions. Such a procedure contributes to the wish-fullfiliment character of religion and, if strictly observed, leads to the insignificance and meaninglessness of religion and religious traditions. Religious thinkers and practitioners must begin to take responsibility for the meaning that they help create, and venture their proclamation (in word and/or deed) on the basis of where they find themselves situated, 1.e.. on the edge that is neither here nor there but always on the way. Only then will the world open up, and the light of the divine shine in.

\section{NOTES}

'Berger, p. 47; Ninian Smart, The Religious Experience of Mankind (New York: Charles Scribner's Sons, 1969), pp. 11-12.

2John Hick, Philosophy of Religion, 2nd ed. (Englewood Cliffs, N.J.: Prentice-Hall, 1973), pp. 1-3. 
'Eaith and Belief (Princeton: Princeton University Press, 1979), p. 171 and passim; Towards a World Theology (Philadelphia: Westminster Press, 1981). Cf. The Meaning and End of Religion (New York: Macmillan, $\overline{19} \overline{6} \overline{1}$.

"Message and Existence: An Introduction to Christian Theology (New York: Seabury, 1979), pp. $\overline{13-14}$, 18 .

Blessed Rage for Order: The New Pluralism in Theology (New York: Seabury, 1975), pp. 32-34, $43 \mathrm{f}$; "The Context: The Public Character of Theological Language" in Tracy and John B. Cobb, Jr.. Talking About God: Doing Theology in the Context of Modern Pluralism (New York: Seabury, 1983), pp. 2, 5 .

"Jacques Derrida, "Differance" in Speech and Phenomena and other Essays on Husserl's Theory of Signs, trans. David B. Allison (Evanston: Northwestern University Press, 1973), pp. 129ff. See also Derrida, Positions, trans. Alan Bass (Chicago: University of Chicago Press, 1981), pp. 8-10, 26-29.

'Jacques Derrida, of Grammatology, trans. G. C. Spivak (Baltimore: Johns Hopkins University Press, 1976). p. 50 .

Ibid.. p. 4.

"Heidegger, "Zur Seinsfrage" in Wegmarken, Gesamtausgabe Band 9 (Erankfurt: Klostermann, 1976), p. 411; Derrida, of Grammatology, pp. $23 \mathrm{ff}, 44$.

1 "Concerning the strange "logic" of parasite and host, see J. Hillis Miller, "The Critic as Host" in Deconstruction and Criticism (New York: Seabury, 1979), pp. $217 \mathrm{ff}$.

"Altizer, "History as Apocalypse" in Deconstruction and Theology (New York: Crossroads/Continuum, 1982 ), pp. 147-77 (Note Mark Taylor's critique of Altizer's Hegelianism in "Altizer's Originality." Journal of the American Academy of Religion 52 (1984), pp. 569-84); Taylor, Erring: A Postmodern A/theology (Chicago: University of Chicago Press, 1984), and Deconstructing Theology (Chico, GA: Scholars Press, 1982); Ricoeur, Interpretation Theory: Discourse and the Surplus of Meaning (Fort Worth: Texas Christian University Press, 1976) (among many others); Gadamer, Truth and Method (New York: Seabury, 1975).

${ }^{12}$ Derrida, Writing and Difference, trans. Alan Bass (Chicago: University of Chicago Press, 1978), p. 259; Heidegger, "On the Being and Conception of Physis in 
Aristotle's Physics B 1," trans. Thomas Sheehan, Man and World $\overline{4}(\overline{1977})$, p. 263. See also Derrida, Pos tions, pp. 44-45, and Heidegger's implicit and expiicit critiques of (Hegelian) dialectics in Hegel's Concept of Experience (New York: Harper and Row, 1970); $\overline{\text { Po- }}$ etry. Language. Thought, trans. Albert Hofstadter ( New York: Harper and Row, 1971), p. 49; Time and Being. trans. Joan Stambaugh (New York: Harper and Row, 1972), pp. $48 \mathrm{ff}$.

"Bølvg, the Fourfold, signifies the emergent meaning--the event of meaning |Ereignis|--that is the play of the world, the play of differing. For an analysis of this theme, particularly as it pertains to the revelation of the divine in religious thinking, see my, "Beyond Theism and Atheism: Heidegger's Significance for Religious Thinking" (Ph.D. dissertation: Temple University, 1984), p. 139ff.

"John B. Cobb, Jr., "God and Buddhism" in Tracy and Cobb, Talking About God, p. 61.

1sDerrida, Margins of Philosoohy, trans. Alan Bass (Chicago: University of Chicago Press, 1982), p. 329, and Disseminations, trans. Barabara Johnson (Chicago: Universit $\frac{1}{\mathrm{f}}$ Chicago Press, 1981), pp. 3ff, calls this "strategy" paleonymy or paleonymics, a "science" of old names that retains the old concept's old name for the emerging new concept in order to communicate and to keep the old opposition inverted or reversed. However. Derrida is often ambiguous about the possibility of eliminating old oppositions. We are here then perlaps following more of a Heideggerian line in pursuing a transformation of our ideas of religious thinking.

"Cf. the idea of "constant practice" of satori (enlightenment) in Zen, i.e., the notion that enlightenment is never a once and for all "experience" that one then has in one's possession, but something that is realized through constant practice.

1 'Heidegger, Being and Time, trans. John Macquarrie and Edward Robinson (New York: Harper and Row, 1962), pp. 302 and passim.

1 Derrida, of Grammatology, pp. 6-26 (entitled "The End of the Book and the Beginning of Writing"). See also Writing and Difference, pp. 64-78 ("Edmond Jabes and the question of the Book'; and Taylor, Erring, pp. 74-93.

"For a fuller discussion of this matter, see Gall, pp. 115-131. 